\title{
OSL DATING USING QUARTZ FINE GRAINS EXTRACTED FROM LOESS IN UPPER PALAEOLITHIC SITES OF NIHEWAN BASIN, NORTHERN CHINA
}

\author{
YORINAO SHITAOKA ${ }^{1}$ and TSUNETO NAGATOMO ${ }^{2}$ \\ ${ }^{I}$ Institute for Geothermal Sciences, Kyoto University, 3088-176 Noguchibaru, Beppu, 874-0903, Japan \\ ${ }^{2}$ Nara University of Education, Takabatake, Nara, 630-8528, Japan
}

Received 30 January 2013

Accepted 4 July 2013

\begin{abstract}
Although radiocarbon $\left({ }^{14} \mathrm{C}\right)$ dating, uranium-series dating, and optically stimulated luminescence (OSL) dating have been conducted for Upper Palaeolithic sites in the Nihewan Basin, northern China, there is room for constructing a detailed chronological framework. In this study, loess sediments collected from two Upper Palaeolithic sites, Youfang site and Hutouliang site, were dated using the single-aliquot regenerative-dose (SAR) OSL protocol. OSL measurements for palaeodoses estimation used fine-grained quartz samples extracted from loess. OSL dating results were obtained as 10-17 ka. These OSL ages were consistent with the related stratigraphy of Palaeolithic sites, archaeological evidence and independent ${ }^{14} \mathrm{C}$ ages.
\end{abstract}

Keywords: OSL dating, Upper Palaeolithic sites, Loess, Nihewan Basin.

\section{INTRODUCTION}

Optically stimulated luminescence (OSL) dating using fine-grained quartz is widely accepted as a reliable tool for use in dating of loess sediments (Watanuki et al., 2003; 2005; Narama et al., 2007; Timar et al., 2010). The chronology of Chinese loess using OSL dating methods has been ascertained (Wang et al., 2006; Lai, 2010).

In this study, OSL dating was performed on loess from Palaeolithic sites of the Nihewan Basin in northern China. The basin is situated $150 \mathrm{~km}$ west of Beijing, covering a wide area of the northwestern part of the Hebei Province and the northeastern part of the Shanxi Province (Fig. 1) (Wei et al., 2011). Many Palaeolithic sites have been discovered in the Nihewan Basin, yielding important information related to archaeology and anthro-

Corresponding author: Y. Shitaoka

e-mail: shitaoka@bep.vgs.kyoto-u.ac.jp pology. Most geochronological studies relevant to the Lower Palaeolithic sites discovered in the Nihewan Basin employed uranium (U) series dating (Chen et al., 1984), electron spin resonance (ESR) dating (Liu et al., 2010a), geomagnetostratigraphic dating, and sedimentology (Zhu et al., 2001; 2004; Liu et al., 2010b; Zuo et al., 2011). The established chronological framework of the Lower Palaeolithic has elucidated the importance of early human evidence in the Nihewan Basin. Nevertheless, few attempts have been made to construct a chronological framework for the Upper Palaeolithic sites in the Nihewan Basin. In the Upper Palaeolithic sites, U-series ages have been obtained for the Xibaimaying site (Xie and $\mathrm{Yu}$, 1989). In addition, ${ }^{14} \mathrm{C}$ ages have been obtained for the Shenquansi site, Nanmo site, Erdaoliang site (Wei et al., 2011), and Hutouliang site (Gai, 1991). Nagatomo et al. (2009) and Zhao et al. (2010) recently conducted OSL dating in this area. However, datasets for a chronological 


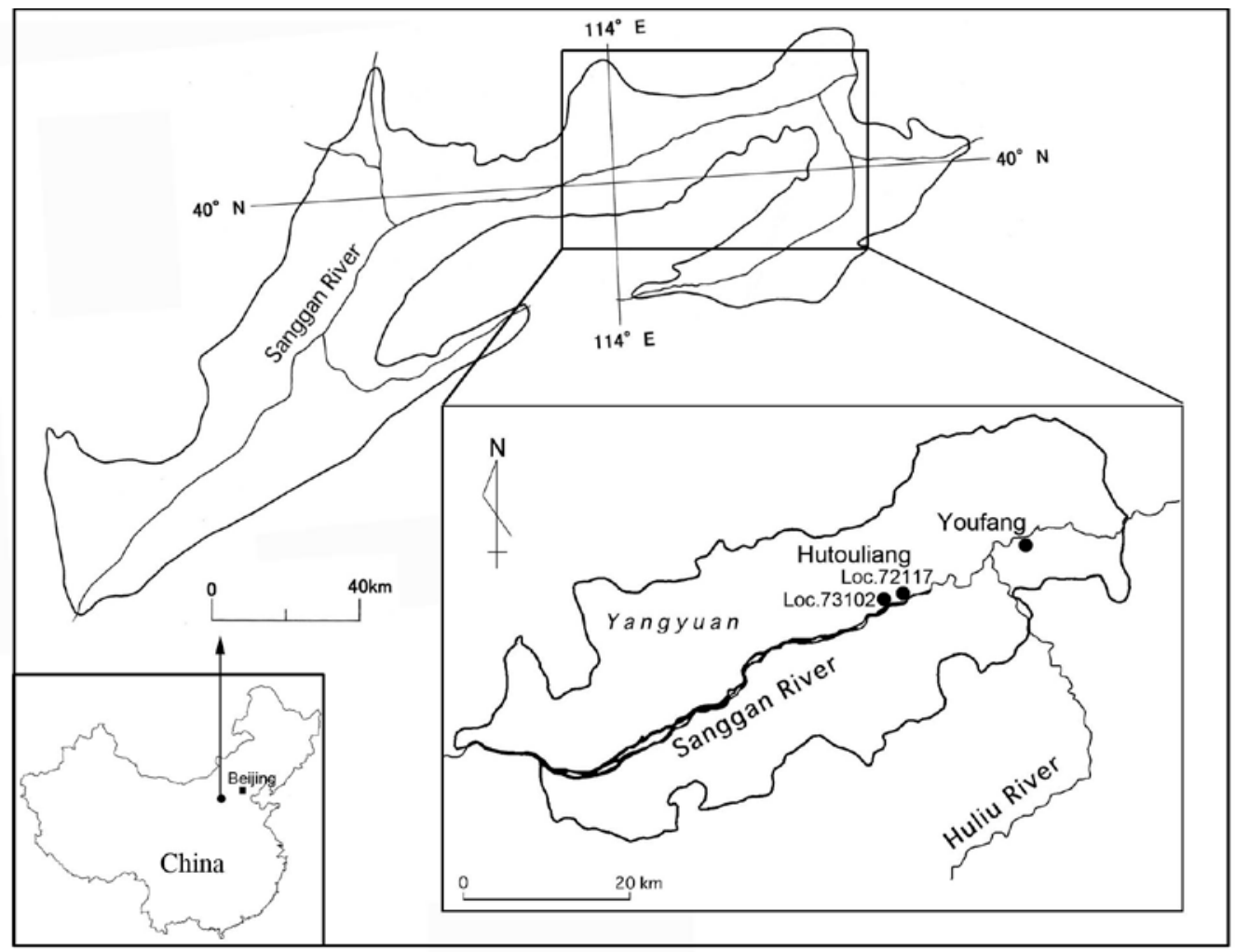

Fig. 1. Location map showing the Nihewan Basin and the Palaeolithic sites described in this paper.

framework of the Upper Palaeolithic sites in the Nihewan Basin are insufficient. Age determination demands accuracy for construction of a chronological framework. Data of Nagatomo et al. (2009) are of especially insufficient accuracy for IRSL age, without fading correction using the multiple aliquot protocol. OSL dating using the single-aliquot regenerative-dose (SAR) protocol (Murray and Wintle, 2000) was used for this study. The SAR protocol using sedimentary quartz is sufficiently accurate for sensitivity correction and estimation of the spread of the palaeodose. The ages obtained as results of this study can be expected to contribute to determination of the detailed chronological framework of the Upper Palaeolithic sites in the Nihewan Basin as key sites exhibiting evidence of microblade technique development.

\section{SAMPLE DETAILS}

The Nihewan Basin, located in the Sanggan River drainage, is filled with Pliocene to Holocene lacustrine, fluvial, and aeolian loess deposits (Wei, 1994). The cultural horizons of the Upper Palaeolithic sites, discovered in the Nihewan Basin, are formed mainly within the aeolian loess deposits (Xie, 2006; Wei et al., 2011).

All samples for OSL dating were collected from loess sediments associated with two Upper Palaeolithic sites, namely Youfang (Xie and Cheng, 1989) and Hutouliang (Gai and Wei, 1977), situated along the eastern margin of the Nihewan Basin (Fig. 1). At the Youfang site, two samples were collected from above (sample YF_No. 1) and below (sample YF_No. 2) (Fig. 2a). Two samples (Fig. 2b) of Loc.73102 were ca. $1.4 \mathrm{~m}$ (73102 No. 1) and $2.1 \mathrm{~m}$ (73102_No. 2), both of which are from above the cultural layer. Two samples (Fig. 2c) of Loc.72117 were taken. Sample 72117_No. 1 was taken from above the cultural layer. Sample 72117 No. 2 was from the cultural layer.

\section{OSL DATING}

\section{Sample preparation}

Minerals in each collected sample were separated into coarse and fine grains (FG) by wet sieving in water. After fine silt (approx. 4-10 $\mu \mathrm{m}$ diameter) was separated by Stokes' law of settling in acetone from FG (Zimmerman,1971), it was treated with $10 \%$ hydrogen peroxide for $16 \mathrm{hr}$ and with $10 \%$ hydrochloric acid for $90 \mathrm{~min}$. To separate the fine-grained quartz, the fine silt samples were immersed in $20 \%$ hydrofluorosilicic acid $\left(\mathrm{H}_{2} \mathrm{SiF}_{6}\right)$ for 9 days. The quartz extract purity was verified using infrared stimulation. We took sample grains showing less than $10 \%$ IRSL compared with blue-stimulated ones. If an infrared signal was measured, indicating the presence of feldspar, then the $\mathrm{H}_{2} \mathrm{SiF}_{6}$ treatment was repeated. 


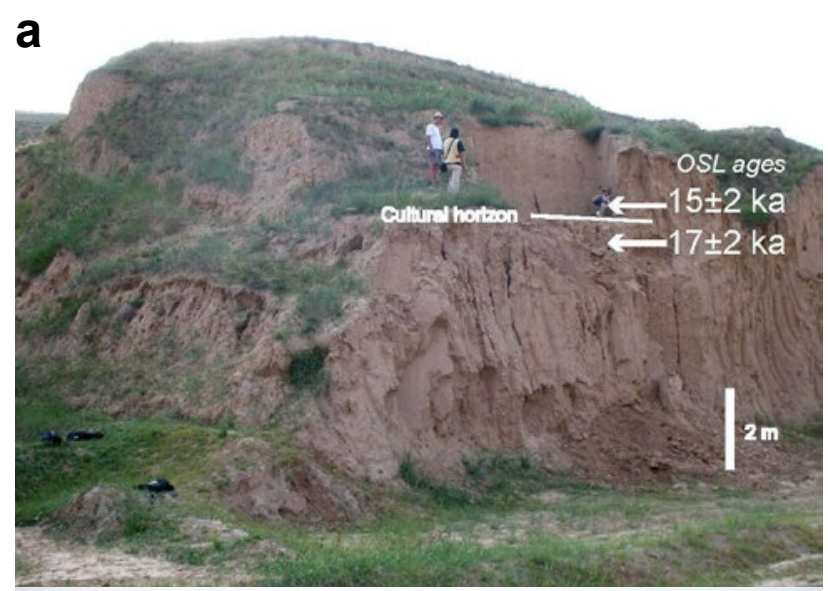

b

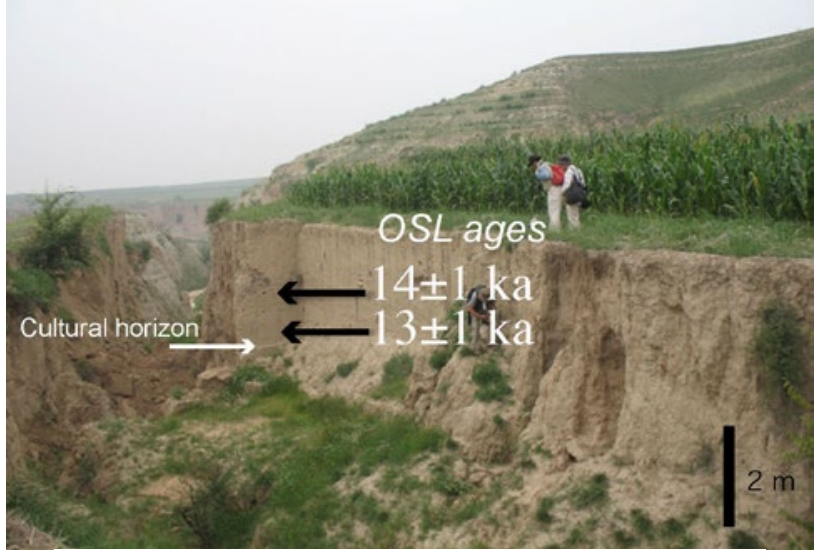

C

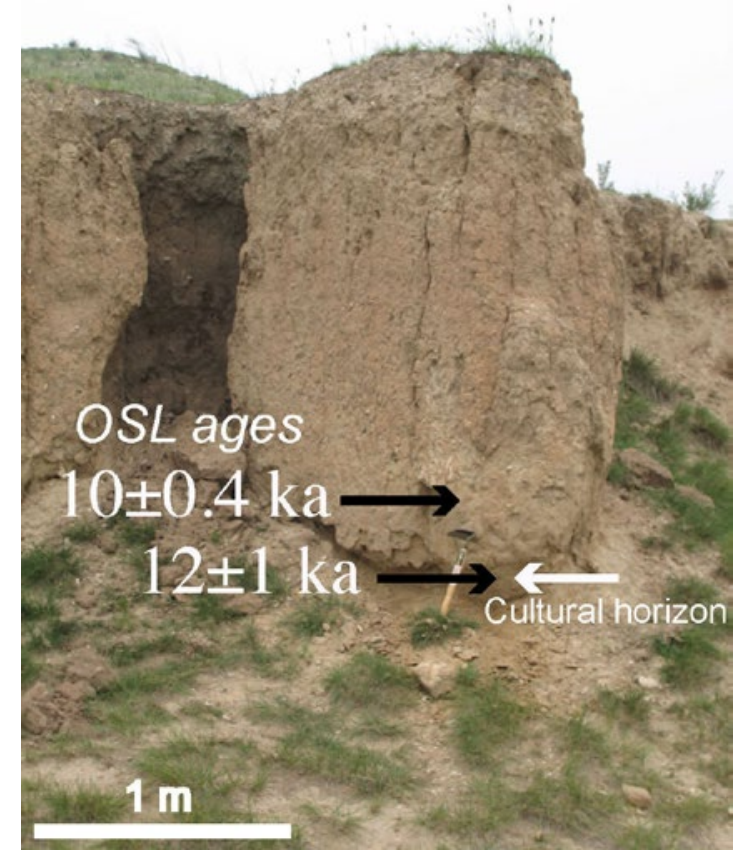

Fig. 2. Photographs of a representative section of each of the Palaeolithic sites: a) Youfang site; b) Loc.73102 of the Hutouliang site; c) Loc.72117 of the Hutouliang site.

\section{Instrumentation and Palaeodose estimation}

All measurements of fine-grained quartz OSL were performed using an OSL/TL reader (NRL-99-OSTL) (Nagatomo et al., 2007; 2009) equipped with an array of 32 blue LEDs $(470 \mathrm{~nm})$ or 32 infrared LEDs $(890 \mathrm{~nm})$. The diameter of each sample disc was $10 \mathrm{~mm}$. An aliquot was $2 \mathrm{mg}$. The OSL from a sample was detected using a photomultiplier tube (R1140P; Hamamatsu Photonics K.K.) housed in a cooling unit, through two condensing lenses and a glass filter ( $2 \mathrm{~mm}$, Hoya U-340; Kenko Tokina Corp.). Irradiation was conducted using a Risø ${ }^{90} \mathrm{Sr} /{ }^{90} \mathrm{Y}$ beta source (dose rate $0.07 \mathrm{~Gy} / \mathrm{s}$ ) built into the OSL reader.

Dose response curves from which palaeodoses could be estimated were constructed using the SAR shown in Table 1. To select appropriate preheating conditions using the SAR protocol, a preheat temperature plateau and dose recovery test was conducted. Preheat temperatures between 200 and $300^{\circ} \mathrm{C}$ were used for $60 \mathrm{~s}$ at intervals of $20^{\circ} \mathrm{C}$. The cut-heat was $160^{\circ} \mathrm{C}$.

\section{Annual dose estimation}

Annual doses (dose rate) were measured using a highresolution gamma-ray spectrometer. The concentrations of ${ }^{238} \mathrm{U},{ }^{232} \mathrm{Th}$, and ${ }^{40} \mathrm{~K}$ in the samples were analyzed using a Ge gamma-ray detector (EGSP 8785; Eurisys Mesures). The annual dose was calculated using the doserate conversion factors reported by Adamiec and Aitken (1998). An alpha efficiency of 0.1 was used, as suggested by Aitken (1998). Present water contents of each sample were used. Contributions of the cosmic dose rate to the annual dose were assumed according to methods proposed in previous reports by Prescott and Hutton (1994), Nagatomo et al. (2009), and Shitaoka et al. (2012).

\section{RESULTS AND DISCUSSION}

A preheat plateau for sample 72117 No. 1 is shown in Fig. 3. A plateau was obtained across the entire preheat range from 200 to $300^{\circ} \mathrm{C}$. Therefore, we selected a preheat temperature of $220^{\circ} \mathrm{C}$ or $240^{\circ} \mathrm{C}$ for routine palaeodose determination in this study. A recuperation test (Wintle and Murray, 2006) was performed for each sample. Recuperation was $<5 \%$ for all samples. The meas-

Table 1. SAR protocol used for this study

\begin{tabular}{clc}
\hline Step & Treatment & Observed \\
\hline $1^{(\mathrm{a})}$ & Give dose, $D_{\mathrm{i}}$ & - \\
2 & Preheat $\left(220-240^{\circ} \mathrm{C}\right.$ for $\left.60 \mathrm{~s}\right)$ & - \\
3 & Stimulate for $100 \mathrm{~s}$ at $120^{\circ} \mathrm{C}$ & $\mathrm{Li}_{\mathrm{i}}$ \\
4 & Give test dose, $3 \mathrm{~Gy}$ or $5 \mathrm{~Gy}$ & - \\
5 & Cut heat $\left(160^{\circ} \mathrm{C}\right)$ & - \\
6 & Stimulate for $100 \mathrm{~s}$ at $120^{\circ} \mathrm{C}$ & $T_{\mathrm{i}}$ \\
7 & Return to 1 & - \\
\hline
\end{tabular}

(a) Step1: For the natural sample, $i=0$ and $D_{0}=0 \mathrm{~Gy}$. 
ured doses in the dose recovery test ( $n=3$ for each sample) were within $\pm 10 \%$ of the administered dose. The result of the dose recovery test for sample 72117 No. 1 is portrayed in Fig. 4. The result suggests that the SAR procedure can recover a laboratory dose.

Each sensitivity-corrected OSL for doses was calculated by dividing $L_{\mathrm{i}}$ by the respective $T_{\mathrm{i}}$ (i.e., $L_{\mathrm{i}} / T_{\mathrm{i}}$ ). The SAR protocol consists of a series of regenerative and testdose measurements to create a sensitivity-corrected growth curve onto which the sensitivity-corrected natural OSL signal $\left(L_{\text {natural }} / T_{\text {natural }}\right)$ is projected. The palaeodose value is obtained from the point of intercept, which is then interpolated onto the dose axis. The value of palaeodose and its error was estimated using a Monte Carlo method (Duller, 2007). For most aliquots, recycling ratios fell within the range of 0.9-1.1. A few aliquots for each sample with a recycling ratio falling outside this range were rejected. Palaeodoses of each sample calculated using the central age model (Galbraith et al., 1999). Radial plots (Vermeesch, 2009) for all samples are presented in Fig. 5. The overdispersion values of YF_No.1 and YF_No.2 were, respectively, $17 \%$ and $12 \%$. Hutouliang samples obtained overdispersion values of $10-15 \%$. Following Olley et al. (2004), a sedimentary sample with overdispersion of less than $20 \%$ was fully bleached. It is assumed that Youfang and Hutoulinag samples have been well-bleached sediments.

All OSL ages are presented in Table 2. The OSL ages of the sites were consistent with their respective stratigraphic positions (Fig. 2). For the samples from Youfang site, OSL ages support the archaeological evidence, which is represented by microblade technology that appeared earlier than industry in Hutouliang (Xie and Cheng, 1989). The OSL ages obtained for Hutouliang Loc. 73102 were consistent with the calibrated ${ }^{14} \mathrm{C}$ ages of 16,310-15,280 cal BP (13,080土120 BP; Xie (2006)).

\section{CONCLUSION}

OSL dating was performed on fine-grained quartz extracted from loess at Palaeolithic sites in the Nihewan Basin of northern China. The OSL-estimated ages give ages of 15-17 ka for the Youfang site and give ages of
10-14 ka for the Hutouliang site. These OSL ages are stratigraphically coherent. Additional dating studies of Upper Palaeolithic sites in the Nihewan Basin would help to further clarify the chronological framework of the Upper Palaeolithic in this area.

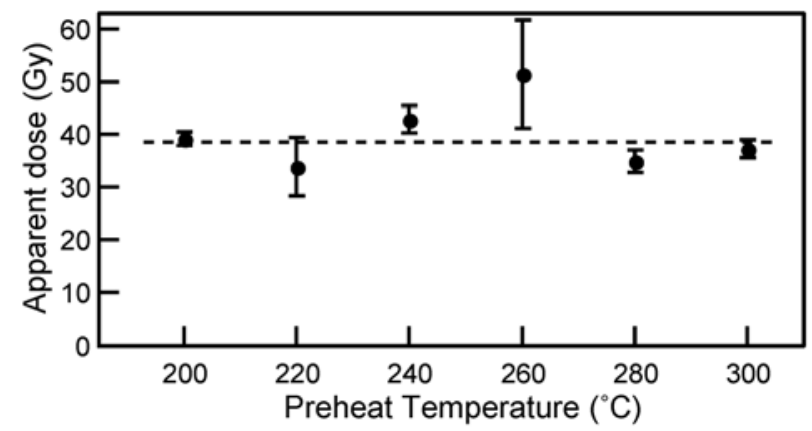

Fig. 3. Preheat temperature plateau dataset of sample 72117_No. 1. Each point represents the average of three aliquots at each temperature.

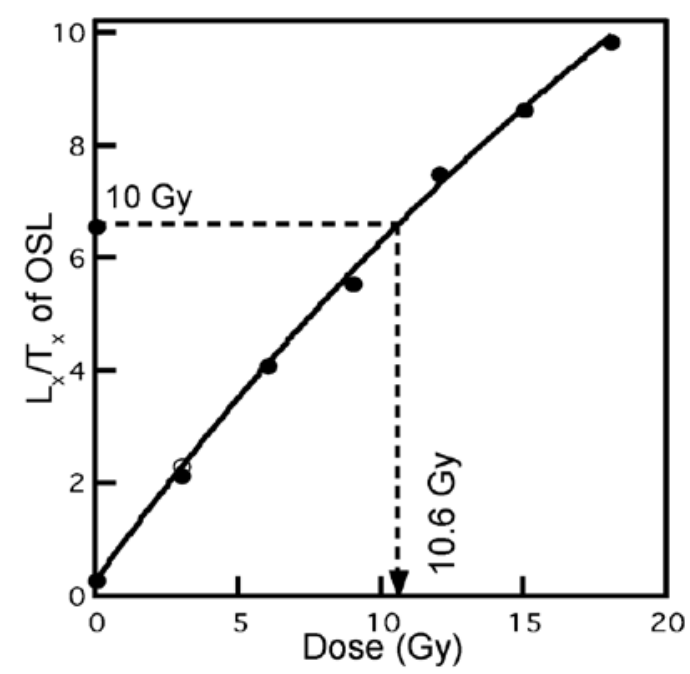

Fig. 4. Dose recovery test of sample 72117_No. 1. The administered dose was $10 \mathrm{~Gy}$. The measured dose was $10.6 \mathrm{~Gy}$.

Table 2. Palaeodose, annual dose and OSL ages for all samples measured in this study.

\begin{tabular}{|c|c|c|c|c|c|c|c|c|c|c|}
\hline Site & $\begin{array}{c}\text { Sample } \\
\text { No. }\end{array}$ & $\begin{array}{l}\text { Palaeo- } \\
\text { dose (Gy) }\end{array}$ & $\begin{array}{l}\text { Aliquots } \\
\text { (n) }\end{array}$ & $\underset{(p p m)}{U}$ & $\begin{array}{c}\text { Th } \\
\text { (ppm) }\end{array}$ & $\begin{array}{c}{ }^{40} \mathrm{~K} \\
(w t \%)\end{array}$ & $\begin{array}{c}\text { Water } \\
\text { content } \\
(\%)\end{array}$ & $\begin{array}{c}\text { Cosmic } \\
\text { dose } \\
\text { (mGyla) }\end{array}$ & $\begin{array}{c}\text { Annual dose } \\
\text { (mGy/a) }\end{array}$ & $\begin{array}{l}\text { OSL age } \\
\text { (ka) }\end{array}$ \\
\hline \multirow{2}{*}{ Youfang } & 1 & $68 \pm 4$ & $7 / 8$ & $2.07 \pm 0.12$ & $10.63 \pm 0.44$ & $1.96 \pm 0.36$ & 1 & 0.15 & $4.60 \pm 0.46$ & $15 \pm 2$ \\
\hline & 2 & $87 \pm 4$ & $8 / 11$ & $2.61 \pm 0.15$ & $10.48 \pm 0.48$ & $2.18 \pm 0.42$ & 1 & 0.15 & $5.05 \pm 0.55$ & $17 \pm 2$ \\
\hline \multirow{2}{*}{$\begin{array}{l}\text { Hutouliang } \\
\text { Loc. } 73102\end{array}$} & 1 & $61 \pm 2$ & $14 / 16$ & $2.90 \pm 0.16$ & $10.03 \pm 0.43$ & $1.65 \pm 0.10$ & 4 & 0.15 & $4.42 \pm 0.10$ & $14 \pm 1$ \\
\hline & 2 & $65 \pm 2$ & $15 / 19$ & $3.00 \pm 0.17$ & $10.45 \pm 0.48$ & $2.07 \pm 0.12$ & 2 & 0.15 & $5.02 \pm 0.13$ & $13 \pm 1$ \\
\hline \multirow{2}{*}{$\begin{array}{l}\text { Hutouliang } \\
\text { Loc. } 72117\end{array}$} & 1 & $40 \pm 1$ & $15 / 15$ & $2.64 \pm 0.15$ & $8.14 \pm 0.43$ & $1.44 \pm 0.10$ & 1 & 0.15 & $3.96 \pm 0.15$ & $10 \pm 0.4$ \\
\hline & 2 & $63 \pm 2$ & $15 / 19$ & $3.34 \pm 0.18$ & $9.56 \pm 0.51$ & $2.00 \pm 0.12$ & 1 & 0.15 & $5.04 \pm 0.16$ & $12 \pm 1$ \\
\hline
\end{tabular}

$n$ is the number of individual aliquots contributing to the Palaeodose estimation against the number of aliquots measured. 

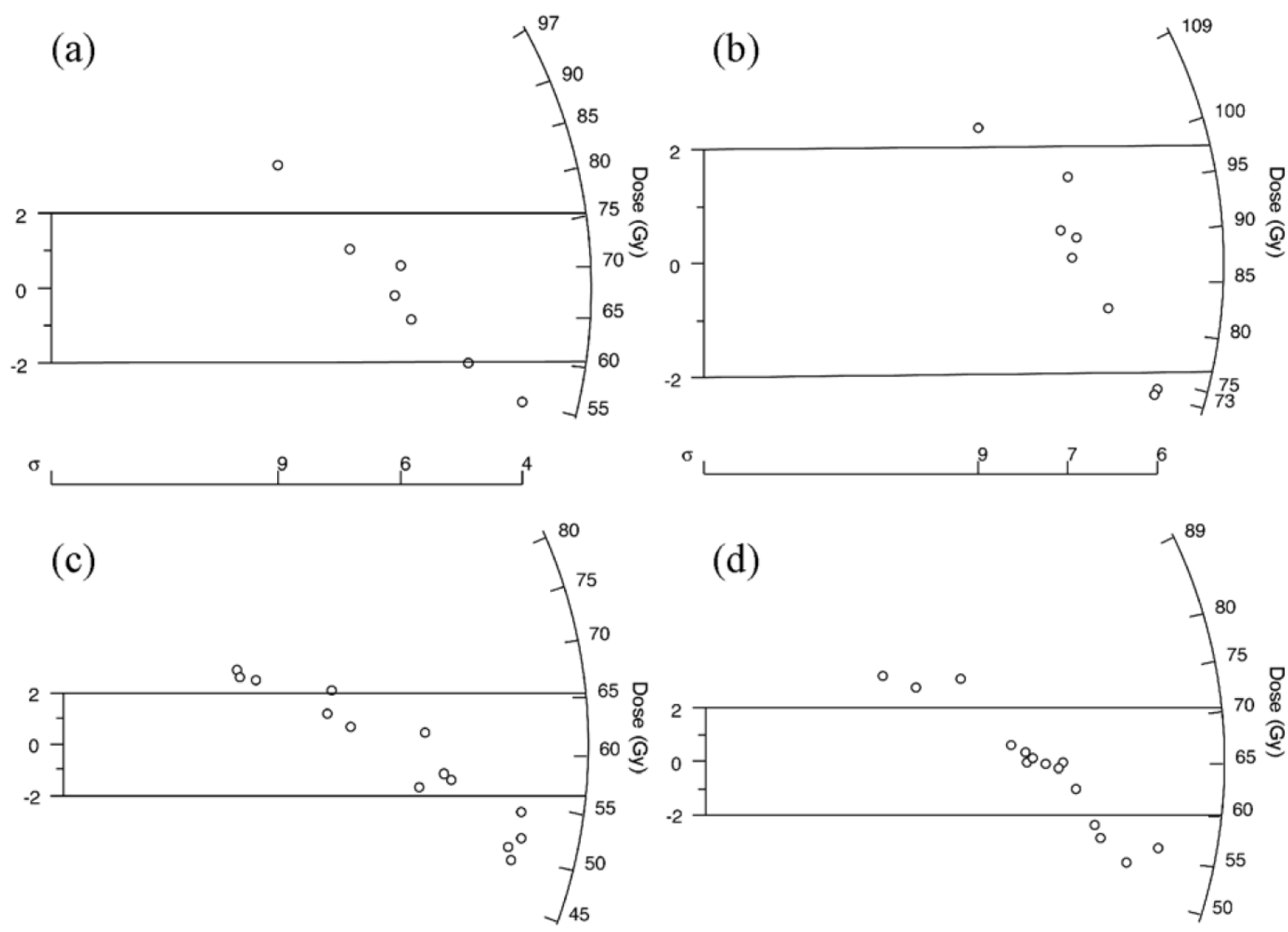

(d)
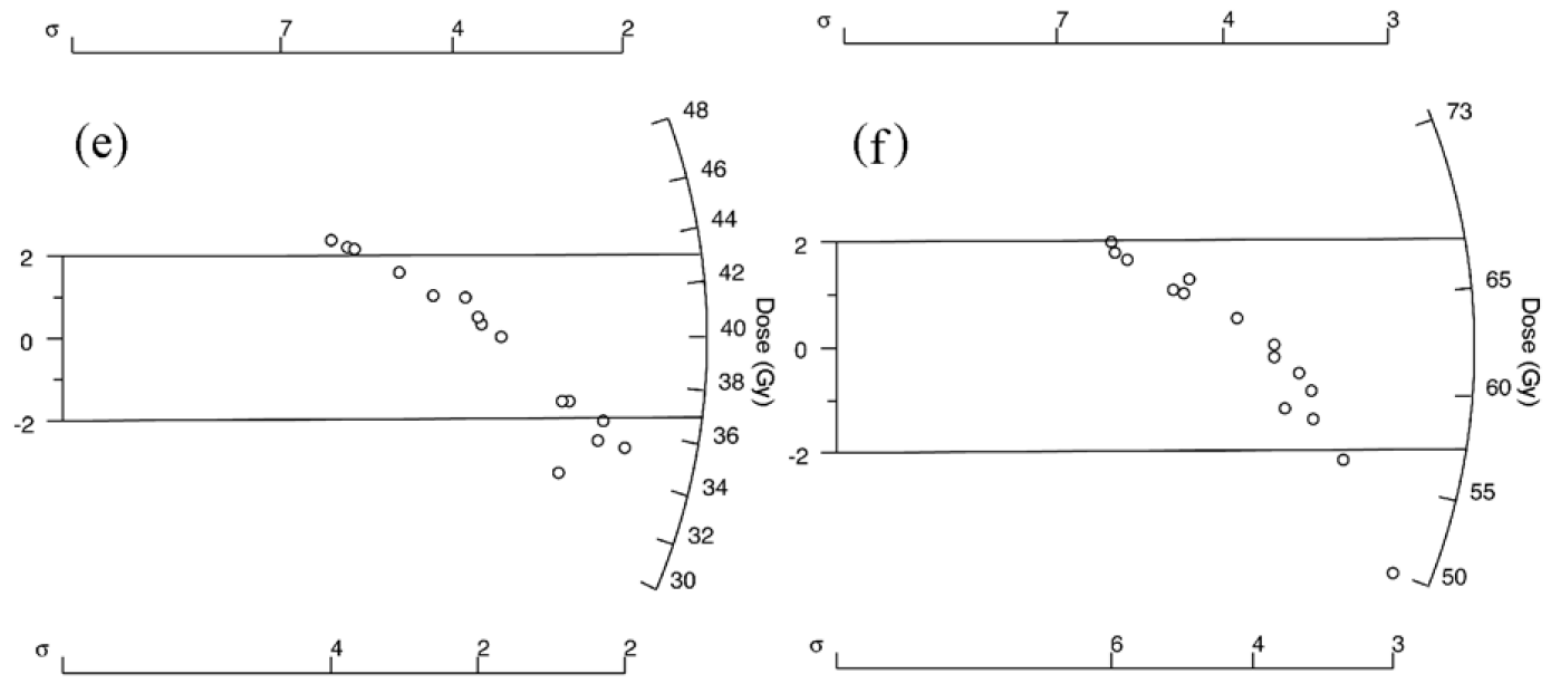

Fig. 5. Dose distributions for all samples are shown using the radial plots: a) YF_No. 1; b) YF_No. 2; c) 73102_No. 1; d) 73102_No. 2; e) 72117_No. 1;f) 72117_No. 2 . 


\section{ACKNOWLEDGMENTS}

We wish to thank Drs. J. Korenaga, M. Sagawa, Q. Wei, X. Gao, M. Oba, K. Ito and N. Hasebe for their advice and help in fieldwork. This work was partially supported by a Grant-in-Aid for Scientific Research (A) and for Young Scientists (B) from the Japan Society for the Promotion of Science (No. 15200059 and No. 23701012).

\section{REFERENCES}

Adamiec G and Aitken MJ, 1998. Dose-rate conversion factors: update. Ancient TL 16: 37-50.

Aitken MJ, 1998. An introduction to optical dating. Oxford University press, New York: 267pp.

Chen TM, Yuan SX and Gao SJ, 1984. The study of Uranium-series dating of fossil bones and an absolute age sequence for the main Palaeolithic sites of northern China. Acta Anthropologica Sinica 3: 259-269. (in Chinese)

Duller GAT, 2007. Assessing the error on equivalent dose estimates derived from single aliquot regenerative dose measurements. $\mathrm{An}$ cient TL 25: 15-24.

Gai P and Wei Q, 1977. Discovery of the late Palaeolithic site on Hutouliang, Hebei. Vertebrata PalAsiatica 15: 287-300. (in Chinese)

Gai P, 1991. Microblade tradition around the northern Pacific Rim: a Chinese perspective. Contributions to the XIII INQUA: 21-31.

Galbraith RF, Roberts RG, Laslett GM, Yoshida H and Olley JM, 1999. Optical dating of single and multiple grains of quartz from Jinmium rock shelter, northern Australia: part 1, experimental design and statistical models. Archaeometry 41(2): 339-364, DOI 10.1111/j.1475-4754.1999.tb00987.x.

Lai ZP, 2010. Chronology and the upper dating limit for loess samples from Luochuan section in the Chinese Loess Plateau using quartz OSL SAR protocol. Journal of Asian Earth Sciences 37(2): 176185, DOI 10.1016/j.jseaes.2009.08.003.

Liu CR, Yin GM, Gao L, Bahain JJ, Li JP, Lin M and Chen SM, 2010a. ESR dating of Pleistocene archaeological localities of the Nihewan Basin, north China - preliminary results. Quaternary Geochronology 5(2-3): 385-390, DOI 10.1016/j.quageo.2009.05.006.

Liu P, Deng CL and Zhu RX, 2010b. Magnetostratigraphic dating of the Huojiadi Palaeolithic site in the Nihewan Basin, north China. Palaeogeography, Palaeoclimatology, Palaeoecology 298(3-4): 399408. DOI 10.1016/j.palaeo.2010.10.027.

Murray AS and Wintle AG, 2000. Luminescence dating of quartz using an improved single-aliquot regenerative-dose protocol. Radiation Measurements 32(1): 57-73. DOI 10.1016/S1350-4487(99)00253$\mathrm{X}$.

Nagatomo T, Shitaoka Y and Kunikita D, 2007. IRSL Dating of the Sediments at the Neolithic Sites in the Russian Far East. Bulletin of Nara University of Education. 56(2): 1-6. (in Japanese with English abstract)

Nagatomo T, Shitaoka Y, Namioka H, Sagawa M and Wei Q, 2009. OSL Dating of the Strata at Palaeolithic Sites in the Nihewan Basin, China. Acta Anthropologica Sinica 28(3): 276-284. (in English and Chinese)

Narama C, Kondo R, Tsukamoto S, Kajiura T, Ormukov C and Abdrakhmatov K, 2007. OSL dating of glacial deposits during the Last Glacial in the Terskey-Alatoo Range, Kyrgyz Republic. Quaternary Geochronology 2(1-4): 249-254, DOI 10.1016/j.quageo.2006.06.007.

Olley JM, De Deckker P, Roberts RG, Fifield LK, Yoshida H and Hancock G, 2004. Optical dating of deep-sea sediments using sin- gle grains of quartz: a comparison with radiocarbon. Sedimentary Geology 169(3-4): 175-189, DOI 10.1016/j.sedgeo.2004.05.005.

Prescott JR and Hutton JT, 1994. Cosmic ray contributions to dose rates for luminescence and ESR dating: Large depths and long-term time variations. Radiation Measurements 23(2-3): 497-500, DOI 10.1016/1350-4487(94)90086-8.

Shitaoka Y, Maemoku H and Nagatomo T, 2012. Quartz OSL dating of sand dunes in Ghaggar Basin, northwestern India. Geochronometria 39(3): 221-226, DOI 10.2478/s13386-012-0012-6.

Timar A, Vandenberghe D, Panaiotu EC, Panaiotu CG, Necula C, Cosma $\mathrm{C}$ and Van den haute $\mathrm{P}, 2010$. Optical dating of Romanian loess using fine-grained quartz. Quaternary Geochronology 5(2-3): 143-148, DOI 10.1016/j.quageo.2009.03.003.

Vermeesch P, 2009. RadialPlotter: A Java application for fission track, luminescence and other radial plots. Radiation Measurements 44(4): 409-410, DOI 10.1016/j.radmeas.2009.05.003.

Wang XL, Lu YC and Wintle AG, 2006. Recuperated OSL dating of fine-grained quartz in Chinese loess. Quaternary Geochronology 1(2): 89-100, DOI 10.1016/j.quageo.2006.05.020.

Watanuki T, Murray AS and Tsukamoto S, 2003. A comparison of OSL ages derived from silt-sized quartz and polymineral grains from Chinese loess. Quaternary Science Reviews 22(10-13): 991-997, DOI 10.1016/S0277-3791(03)00053-2.

Watanuki T, Murray AS and Tsukamoto S, 2005. Quartz and polymineral luminescence dating of Japanese loess over the last 0.6 Ma: Comparison with an independent chronology. Earth and Planetary Science Letters 240(3-4): 774-789, DOI 10.1016/j.eps1.2005.09.027.

Wei Q, 1994. Banshan Palaeolithic site from the lower Pleistocene in the Nihewan basin in northern China. Acta Anthropologica Sinica 13: 223-238. (in Chinese)

Wei Q, Lin J and Pei SW, 2011. Palaeolithic sites and the ancient culture. In: Yuan BY, Xia ZK and Niu PS, eds, Nihewan rift and early man. Geological Publishing House, Beijing: 132-207. (in Chinese)

Wintle AG and Murray AS, 2006. A review of quartz optically stimulated luminescence characteristics and their relevance in singlealiquot regeneration dating protocols. Radiation Measurements 41(4): 369-391. DOI 10.1016/j.radmeas.2005.11.001.

Xie F and Yu SF, 1989. A study of Palaeolithic remains from Xibaimaying, Yangyuan, Hebei. Wenwu Chunqiu 3: 13-26. (in Chinese with English abstract)

Xie F and Cheng SQ, 1989. Excavation report of the Youfang microlithic site at Yangyuan. Acta Anthropologica Sinica 8: 59-68. (in Chinese)

Xie F, 2006. Nihewan. Cultural Relics Press, Beijing: 330pp. (in Chinese with English abstract)

Zhao H, Lu YC, Wang CM, Chen J, Liu JF and Mao HL, 2010. ReOSL dating of Aeolian and fluvial sediments from Nihewan Basin, northern China and its environmental application. Quaternary $\mathrm{Ge}$ ochronology 5(2-3): 159-163, DOI 10.1016/j.quageo.2009.03.008.

Zhu RX, Hoffman KA, Potts R, Deng CL, Pan YX, Guo B, Shi CD, Guo ZT, Yuan BY, Hou YM and Huang WW, 2001. Earliest presence of humans in northeast Asia. Nature 413: 413-417, DOI $10.1038 / 35096551$

Zhu RX, Potts R, Xie F, Hoffman KA, Deng CL, Shi CD, Pan YX, Wang HQ, Shi RP, Wang YC, Shi GH and Wu NQ, 2004. New evidence on the earliest human presence at high northern latitudes in northeast Asia. Nature 431: 559-562, DOI 10.1038/nature02829.

Zimmerman DW, 1971. Thermoluminescent dating using fine grains from pottery. Archaeometry 13(1): 29-52, DOI 10.1111/j.14754754.1971.tb00028.x.

Zuo TW, Cheng HJ, Liu P, Xie F and Deng CL, 2011. Magnetostratigraphic dating of the Hougou Palaeolithic site in the Nihewan basin, north China. Science China Earth Sciences 54(11): 1643-1650, DOI 10.1007/s11430-011-4221-2. 